J. Dairy Sci. 104:11334-11334

https://doi.org/10.3168/jds.2021-104-10-11334

() 2021 American Dairy Science Association ${ }^{\circledR}$. Published by Elsevier Inc. and Fass Inc. All rights reserved.

\title{
Corrigendum to "Effects of high-starch or high-fat diets formulated to be isoenergetic on energy and nitrogen partitioning and utilization in lactating Jersey cows" (J. Dairy Sci. 103:4378-4389)
}

\section{L. Morris, T. M. Brown-Brandl, K. E. Hales, K. J. Harvatine, and P. J. Kononoff}

Tissue energy was calculated incorrectly. The corrected equation is listed below, as well as a corrected Table 3 , with corrected tissue energy (TE) and $\mathrm{NE}_{\mathrm{L}}$ values calculated using tissue energy (corrected text shown in bold).

Tissue energy $\left(\right.$ Mcal of $\left.\mathrm{NE}_{\mathrm{L}} / \mathrm{d}\right)=$ positive residual energy $\times \mathbf{k}_{\mathrm{G}} / \mathbf{k}_{\mathbf{T}}$ or negative residual energy $\times \mathbf{k}_{\mathrm{T}}$,

where $k_{\mathrm{T}}$ is the efficiency of utilizing body reserve energy for milk production and $\mathrm{k}_{\mathrm{G}}$ is the efficiency of utilizing ME intake for tissue gain. Values of 0.82 and 0.75 were used for $k_{T}$ and $k_{G}$, respectively (NRC, 2001).

Table 3. Effects of a high-starch (HS) or high-fat (HF) diet fed to lactating Jersey cows on energy partitioning and utilization

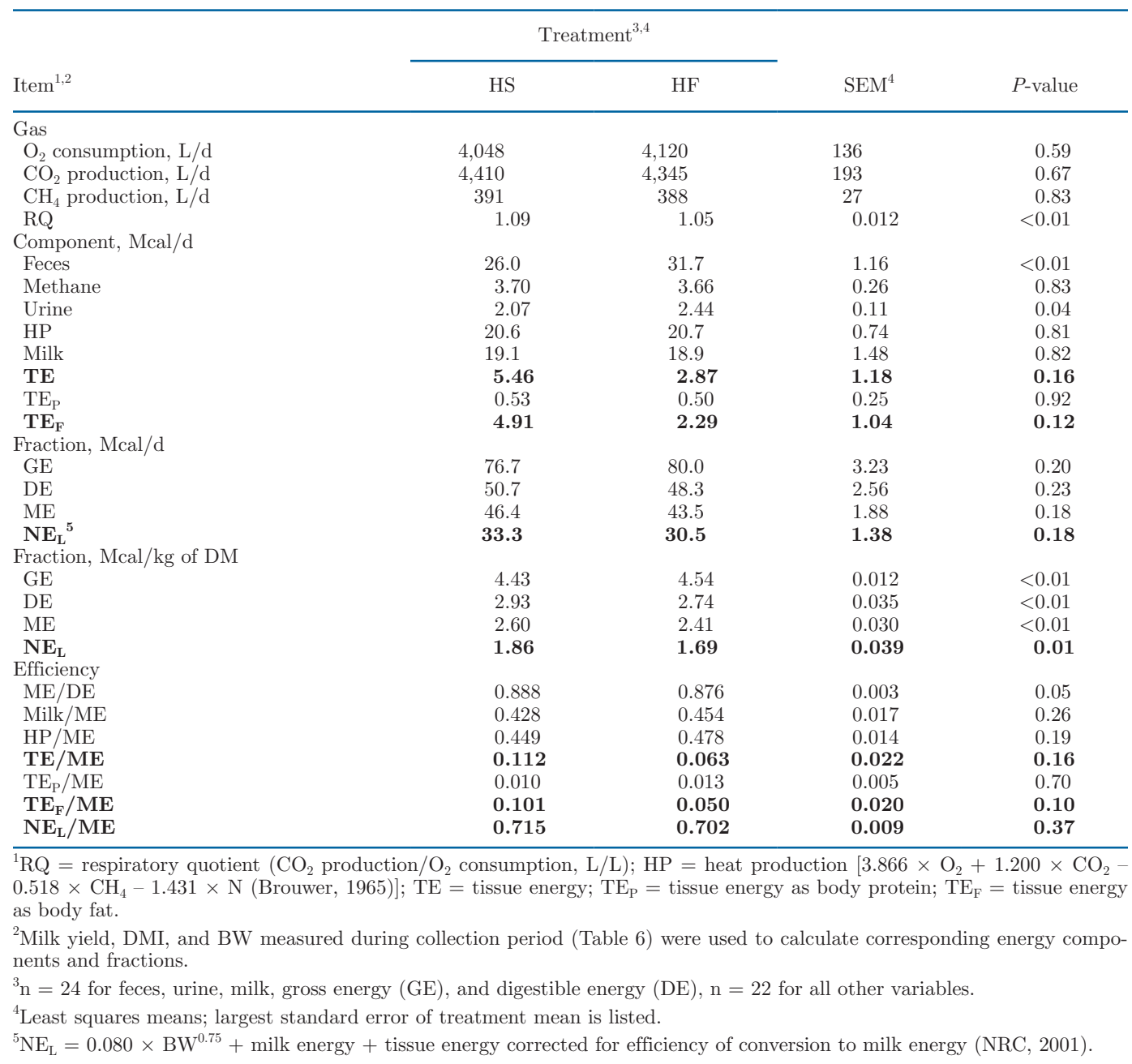

\section{REFERENCE}

Morris, D. L., T. M. Brown-Brandl, K. E. Hales, K. J. Harvatine, and P. J. Kononoff. 2020. Effects of high-starch or high-fat diets formulated to be isoenergetic on energy and nitrogen partitioning and utilization in lactating Jersey cows. J. Dairy Sci. 103(5):4378-4389. https://doi .org/10.3168/jds.2019-17638. 